\title{
The STEAP I 262-270 Peptide Encapsulated into PLGA Microspheres Elicits Strong Cytotoxic T Cell Immunity in HLA-A*020I Transgenic Mice-A New Approach to Immunotherapy Against Prostate Carcinoma
}

\author{
Valerie L. Herrmann, ${ }^{1}$ Daniel E. Wieland, ${ }^{2}$ Daniel F. Legler, ${ }^{3}$ Valentin Wittmann, ${ }^{2}$ \\ and Marcus Groettrup ${ }^{1,3 *}$ \\ 'Division of Immunology, Department of Biology, University of Konstanz, Konstanz, Germany \\ ${ }^{2}$ Department of Chemistry, University of Konstanz, Konstanz, Germany \\ ${ }^{3}$ Biotechnology Institute Thurgau (BITg) at the University of Konstanz, Kreuzlingen, Switzerland
}

\begin{abstract}
BACKGROUND. PLGA microsphere-based vaccination has been proven to be effective in immunotherapy of syngeneic model tumors in mice. The critical step for the translation to humans is the identification of immunogenic tumor antigens and potent vaccine formulations to overcome immune tolerance.

METHODS. HLA-A*0201 transgenic mice were immunized with eight different human prostate cancer peptide antigens co-encapsulated with TLR ligands into PLGA microspheres and analyzed for antigen-specific and functional cytotoxic T lymphocyte responses.

RESULTS. Only vaccination with STEAP1 $1_{262-270}$ peptide encapsulated in PLGA MS could effectively crossprime CTLs in vivo. These CTLs recognized STEAP1 $1_{262-270} /$ HLA-A*0201 complexes on human dendritic cells and prostate cancer cell lines and specifically lysed target cells in vivo. Vaccination with PLGA microspheres was much more potent than with incomplete Freund's adjuvant.

CONCLUSIONS. Our data suggests that there exist great differences in the immunogenicity of human PCa peptide antigens despite comparable MHC class I binding characteristics. Immunogenic STEAP $1_{262-270}$ peptide encapsulated into PLGA microspheres however was able to induce vigorous and functional antigen-specific CTLs and therefore is a promising novel approach for immunotherapy against advanced stage prostate cancer.
\end{abstract}

KEY WORDS: prostate cancer; tumor antigen; STEAP; cancer vaccine; PLGA microspheres

\section{INTRODUCTION}

With 233,000 new cases and 29,480 estimated deaths, prostate cancer (PCa) is the second-leading cause of cancer-related deaths in the United States in 2014 [1]. The majority of patients diagnosed with localized PCa are successfully treated with radiation therapy or radical prostatectomy [2,3]. However, within 10 years around $30 \%$ of patients eventually fail on local therapy and progress to advanced-stage or metastatic PCa. Androgen deprivation therapy is the standard care for patients with advanced PCa, although most tumors become resistant to primary hormonal therapy within 14-30 months [4]. For men with metastatic castration resistant prostate

Grant sponsor: German Cancer Aid; Grant sponsor: Horizon 2020 NMP; Grant number: 6860892

Conflict of interest: Nothing to declare.

*Correspondence to: Marcus Groettrup, Division of Immunology, Department of Biology, University of Konstanz, Konstanz 78457, Germany. E mail: marcus.groettrup@uni konstanz.de 
cancer (mCRPC) docetaxel chemotherapy in combination with prednisone was the only treatment option for more than a decade [5]. New agents, including abiraterone acetate, cabazitaxel, enzalutamide, and radium-223 dichloride were shown to prolong life for men with advanced PCa for several months [6-9]. The first approved cell-based immunotherapy, sipuleucel-T, afforded an increase of overall survival of 4.5 months [10]. This limited efficacy and high costs associated with in vitro loading of autologous antigen presenting cells fostered attempts to develop vaccination approaches relying on in vivo loading of antigen presenting cells (APCs) with antigen and immune stimulants. Such vaccination regimens might be combined with the administration of monoclonal antibodies blocking CTLA-4 and PD1 signaling that function as immune checkpoint inhibitors [11,12].

$\mathrm{CD}^{+}$cytotoxic $\mathrm{T}$ cells can efficiently recognize and destroy tumor cells which expose peptides derived from intracellular tumor-associated antigens (TAAs) in complex with MHC class I molecules on their surface [13]. These TAAs include proteins preferentially expressed in normal prostate tissue but are overexpressed in PCa. The first TAA for PCa was prostate-specific antigen (PSA), a kallikrein-like serine-protease that is almost exclusively expressed by prostate epithelial cells and can be detected in the majority of PCa tissues, and represents the most widely used serum marker for diagnosis and monitoring of PCa [14]. Another marker for normal prostate cells but also for the majority of prostate tumors, especially undifferentiated, metastatic $\mathrm{PCa}$ is the integral membrane glycoprotein prostate-specific membrane antigen (PSMA) [15]. Prostatic acid phosphatase (PAP) is a glycoprotein with enzymatic activity that is mainly secreted by prostate epithelial cells in benign and malignant prostate tissue [16]. Its main expression in the prostate and in more than $80 \%$ of primary PCa samples turns the glycosylphosphatidylinositol-anchored cell surface protein prostate stem cell antigen (PSCA) into an attractive antigen for immunotherapy, too $[17,18]$. Both transmembrane proteins, transient receptor potential melastatin 8 (TRPM8) and six-transmembrane epithelial antigen of the prostate 1 (STEAP1) are detectable in the majority of prostate tumors with TRPM8 being predominantly overexpressed in the first stages and lower grades of cancer [19] and the latter being detectable in different stages and metastases of PCa but also in a variety of other tumors, including bladder, colon, and ovarian cancer $[20,21]$. As an inhibitor of apoptosis, survivin is highly overexpressed in many human tumors, including PCa with its expression correlating with aggressiveness and poor prognosis [22].
On the basis of the crucial role of $\mathrm{T}$ cells in the elimination of tumor cells much attention has been paid to the identification of these TAAs and derived HLA class I-restricted T cell epitopes for the design of novel $\mathrm{T}$ cell-based immunotherapies. However, tumor cells develop from self-tissues, and therefore, the immune system is largely tolerant to them. The main objective of cancer immunotherapy thus is to strongly stimulate the immune system to boost the natural anti-tumor immunity [23]. We and other groups have investigated poly(D,L-lactide-co-glycolide) microspheres (PLGA MS) as antigen delivery system targeting dendritic cells (DCs) and macrophages in vitro and in vivo as an alternative to incomplete Freund's adjuvant (IFA) which has failed to be approved for routine clinical use [24-27]. Uptake of the antigens and TLR ligands encapsulated in PLGA MS by APCs does not negatively affect their cardinal properties like migratory capacity, cytokine secretion, and antigen presentation [28]. In addition, PLGA MS have beneficial properties like the protection of their content from degradation and the long-lasting depot effect for sustained and prolonged immune responses $[29,30]$. The addition of potent immune-enhancing adjuvants like cytosine-phosphorothioate-guanine oligodeoxynucleotides (CpG-ODN) or polyriboinosinic:polyribocitidylic acid (polyI:C) is necessary for the maturation and crosspriming ability of the APCs. For the generation of a potent immune response TLR ligand and antigen need to be co-encapsulated into the same PLGA MS to be targeted into the same endosome [31].

In this study, we examined the immunogenicity of eight different HLA-A*0201 restricted PCa peptide antigens. We show that despite similar encapsulation efficiencies and release profiles from PLGA MS and comparable binding characteristics to HLA-A*0201 only one out of the eight antigens was able to prime CTLs in vivo. These CTLs, however, were highly peptide-specific and fully functional, as they were able to specifically lyse target cells in vivo. In addition, the peptide specific CTLs were able to recognize the peptide/HLA ${ }^{*} 0201$ complex both on human cells and prostate cancer cell lines and to elicit thereupon an immune response.

\section{MATERIALS AND METHODS}

\section{Preparation of Microspheres}

Microspheres (MS) were prepared from $14 \mathrm{kDa}$ PLGA 50:50 carrying hydroxyl- and carboxyl-end groups (Resomer ${ }^{\circledR}$ RG502H, Evonik Röhm $\mathrm{GmbH}$ ). The synthetic peptides $\mathrm{PSA}_{154-163}, \mathrm{PSCA}_{14-22}, \mathrm{PAP}_{112-120}$, TRPM8 $_{187-195}$, PSMA $_{27-35}$, Survivin ${ }_{96-104}$, STEAP1 $_{86-94}$, 
and STEAP1 $1_{262-270}$ from human prostate and TLR ligands were microencapsulated by spray drying as described elsewhere [32]. Briefly, $10 \mathrm{mg}$ peptide and $5 \mathrm{mg}$ CpG oligodeoxynucleotides with a phosphothioate backbone (CpG ODN 1826, Microsynth) or $0.5 \mathrm{mg}$ polyI: C (Sigma-Aldrich) were dissolved in $0.5 \mathrm{ml} 0.1 \mathrm{M}$ $\mathrm{NaHCO}_{3}$ and mixed with $1 \mathrm{~g}$ of PLGA dissolved in $20 \mathrm{ml}$ dichloromethane. The aqueous and the organic phase were homogenized under ultrasonication for 10 sec on ice. The obtained w/o dispersion was immediately spray dried (Büchi, Mini Spray-Dryer 191) at a flow rate of $2 \mathrm{ml} / \mathrm{min}$ and inlet/outlet temperatures of $40^{\circ} \mathrm{C} /$ $37^{\circ} \mathrm{C}$. The obtained MS were washed out of the spraydryer's cyclone with $0.05 \%$ poloxamer 188 (Synperonic ${ }^{\circledR}$ F68, Serva Electrophoresis), collected on a cellulose acetate membrane filter and dried under reduced pressure ( $20 \mathrm{mbar}$ ) for $18 \mathrm{hr}$ at room temperature. MS were stored at $4^{\circ} \mathrm{C}$. Immediately before use, MS were dispersed in PBS by ultrasonication for $30 \mathrm{sec}$ to obtain a homogeneous MS suspension.

\section{Mice and Immunizations}

HLA-A*0201 transgenic mice (AAD mice [33]) were originally obtained from Charles River Laboratories. All mice were kept in a specific pathogen-free facility and used at 6-12 weeks of age. Animal experiments were approved by the Review Board of Regierungspräsidium Freiburg. Mice were immunized with a mixture of $5 \mathrm{mg}$ peptide/CpG MS and $5 \mathrm{mg}$ polyI:C MS or the respective amounts of peptide $(50 \mu \mathrm{g})$, CpG-ODN (25 $\mu \mathrm{g})$, and polyI:C (2.5 $\mu \mathrm{g})$ emulsified in PBS:IFA (1:1). Control mice were treated with adjuvants MS corresponding to $5 \mathrm{mg}$ CpG-ODN MS $(25 \mu \mathrm{g})$ and $5 \mathrm{mg}$ polyI:C MS $(2.5 \mu \mathrm{g})$.

\section{Characterization of the PLGA MS}

To characterize the PLGA MS, encapsulation efficiency and release of the two peptides was analyzed. For the determination of the encapsulation efficiency, $5 \mathrm{mg}$ MS were dissolved in $200 \mu \mathrm{l}$ acetone. The solvent was evaporated with vacuum centrifugation and the pellet was resuspended in MilliQ water under ultrasonication. Release of the peptides from the PLGA MS was identified by dispersing $5 \mathrm{mg}$ PLGA MS in $200 \mu \mathrm{l}$ PBS by ultrasonication for $30 \mathrm{sec}$. After an incubation at $37^{\circ} \mathrm{C}$ under agitation for 6 days, samples were spun down. Peptide contents of the supernatants were determined using the MicroBCA ${ }^{\mathrm{TM}}$ Protein Assay Kit (Life Technologies) according to the manufacturer's protocol using the respective peptide as standard. Assessed amounts were compared to theoretical maximal loading and given in \% encapsulation efficiency.

\section{Peptide Binding Assay}

Each peptide was tested for concentration-dependent HLA-A*0201 stabilization on T2 cells. T2 cells were washed twice in serum-free IMDM and incubated at room temperature overnight with the candidate peptides over a concentration range from 0.5 to $10 \mu \mathrm{M}$ in the presence of $1 \mu \mathrm{g} / \mathrm{ml} \beta_{2}$-microglobulin. T2 cells were washed twice and stained with an APC-conjugated anti-human HLA-A2 antibody clone BB7.2 (eBioscience). The peptide GILGFVFTL of influenza virus matrix1 protein residues 58-66, was used as positive control; incubation with PBS served as negative control. For the off-kinetics, T2 cells were incubated overnight at room temperature with $10 \mu \mathrm{M}$ of the respective peptide followed by an incubation at $37^{\circ} \mathrm{C}$ in the presence of $50 \mu \mathrm{g} / \mathrm{ml}$ cycloheximide. After 1, 2, 3, 4, and $6 \mathrm{hr}$ the loss of HLA-A*0201 molecules from the surface was monitored by flow cytometry.

\section{Intracellular Cytokine Staining}

Intracellular cytokine staining (ICS) was performed to detect intracellular interferon gamma $(\mathrm{IFN}-\gamma)$ as a measure of CTL activation. Splenocytes were isolated by mechanical disruption. The isolated cells were incubated with or without $10 \mu \mathrm{M}$ of the respective peptide in the presence of $10 \mu \mathrm{M} / \mathrm{ml}$ brefeldin A for $5 \mathrm{hr}$ at $37^{\circ} \mathrm{C}$. After washing, the cells were stained with APC-conjugated rat anti-mouse CD8 $\alpha$ antibody clone 53-6.7 (eBioscience) for $20 \mathrm{~min}$ at $4^{\circ} \mathrm{C}$. The cells were washed twice before they were fixed with $4 \%$ paraformaldehyde in PBS for $5 \mathrm{~min}$ at $4^{\circ} \mathrm{C}$. Afterwards, cells were washed twice with $\mathrm{PBS} / 0.1 \%$ saponin for permeabilization and were then labeled intracellularly with FITC-conjugated rat anti-IFN- $\gamma$ antibody clone XGM1.2 or FITC-conjugated rat IgG1 $\kappa$ isotype control antibody in $\mathrm{PBS} / 0.1 \%$ saponin overnight at $4^{\circ} \mathrm{C}$. The next day, cells were washed twice and were resuspended in FACS buffer (PBS, 2\% FCS, 2 mM EDTA, $2 \mathrm{mM}$ $\mathrm{NaN}_{3}$ ) for flow cytometry.

\section{ELISPOT}

A commercially available antibody pair (BD Biosciences) for the detection of IFN- $\gamma$ producing cells was used according to the manufacturer's protocol. ELISPOT 96 well plates were coated with anti-IFN- $\gamma$ antibody and subsequently blocked. Splenocytes were incubated with or without $10 \mu \mathrm{M}$ of the respective peptide overnight at $37^{\circ} \mathrm{C}$. After incubation with a biotinylated antibody for $2 \mathrm{hr}$, a streptavidin-alkaline phosphatase enzyme conjugate was added for $40 \mathrm{~min}$ at room temperature. Spots of the dried plate were 
counted using an ImmunoScan instrument (C.T.L., Cellular Technology Ltd.).

\section{Peptide/HLA-A*020I Recognition Assay}

Mice were immunized with a mixture of $5 \mathrm{mg}$ $\mathrm{STEAP}_{262-270} / \mathrm{CpG} \mathrm{MS}$ and $5 \mathrm{mg}$ polyI:C MS. After 6 days, splenocytes were isolated by mechanical disruption. The isolated splenocytes were co-incubated with STEAP1 $1_{262-270}$ peptide or STEAP1 ${ }_{262-270}$ presenting human $\mathrm{HLA} \mathrm{A}^{*} 0201$ positive cells overnight. LNCaP, PC3 and DU154 were transiently transfected with pAADneo vector (kind gift of V.H. Engelhard, Charlottesville, VA) and maintained in RPMI 1640 supplemented with $10 \% \mathrm{FCS}, 1 \% \mathrm{P} / \mathrm{S}$ and $500 \mu \mathrm{g} / \mathrm{ml}$ geneticin G418.Transfected cell lines were screened and sorted for $\mathrm{AAD}$ expression by flow cytometry using the APC-conjugated anti-human HLA-A2 antibody clone BB7.2 (eBioscience). Ninety-five percent of the PC3 cells and $82 \%$ of the LNCaP and DU154 cells expressed AAD 2 days after the sort and are referred to as PC3-AAD, LNCaP-AAD, DU154-AAD. These transfectants or T2 cells were incubated at $37^{\circ} \mathrm{C}$ for $1 \mathrm{hr}$ with or without $10{ }^{6} \mathrm{M} \mathrm{STEAP} 1_{262-270}$ peptide, washed twice and then used for the recognition assay. Human monocyte-derived dendritic cells (MoDCs) were generated from peripheral blood mononuclear cells (PBMC) as previously described [34]. In brief, heparinized blood was taken from HLA-A*0201 positive donors to obtain PBMC by density gradient centrifugation on Ficoll-Paque1 at 1,800 rpm for $20 \mathrm{~min}$. After magnetic sorting for $\mathrm{CD}_{14}{ }^{+}$monocytes (Miltenyi Biotec), cells were further cultured for 5 days in AIM-V containing $1,000 \mathrm{U} / \mathrm{ml}$ of GM-CSF and $800 \mathrm{U} / \mathrm{ml}$ of IL-4. On day $5,0.25 \mathrm{mg} \mathrm{STEAP1}_{262-270} / \mathrm{CpG} \mathrm{MS}$ or CpG MS were added to $1 \times 10^{6}$ immature MoDCs. After 2 days of maturation, MoDCs were washed twice and were then used for the recognition assay. Analysis was performed by ELISPOT assay or ELISA for IFN- $\gamma$.

\section{ELISA}

For the detection of IFN- $\gamma$ secretion by PLGA MS induced CTLs, supernatants of the recognition assay were analyzed using a mouse IFN- $\gamma$ ELISA kit (BD Biosciences) according to the manufacturer's instructions.

\section{In Vivo Cytotoxicity Assay}

For the analysis of the cytotoxic activity of CTLs in vivo, splenocytes from naïve mice were depleted from erythrocytes. Half of the cells was left untreated, the other half was pulsed with
$10{ }^{6} \mathrm{M}$ peptide for $1 \mathrm{hr}$ at $37^{\circ} \mathrm{C}$. Afterwards, untreated and peptide pulsed cells were stained with $1 \mu \mathrm{M} / 10 \mu \mathrm{M}$ CFSE, respectively, for $10 \mathrm{~min}$ at $37^{\circ} \mathrm{C}$. A mixture of $1 \times 10^{7}$ pulsed and unpulsed cells in a total volume of $200 \mu$ l was injected i.v. in the tail vein of mice that were immunized with peptide/CpG MS and $5 \mathrm{mg}$ polyI:C MS or control mice that received $5 \mathrm{mg}$ CpG MS and $5 \mathrm{mg}$ polyI:C MS 5 days before. After $24 \mathrm{hr}$ splenocytes and liver lymphocytes of the immunized mice were analyzed for CFSE-labeled cells by flow cytometry. Splenocytes were isolated by mechanical disruption of the spleen. For isolation of liver lymphocytes, the liver was cut into small pieces and digested at $37^{\circ} \mathrm{C}$ in IMDM containing $0.2 \mathrm{mg} / \mathrm{ml}$ of collagenase $\mathrm{D}$ (Roche), $0.2 \mathrm{mg} / \mathrm{ml}$ of DNase I (Roche), 10\% FCS, $100 \mathrm{U} / \mathrm{ml} \mathrm{P/S}$ for $45 \mathrm{~min}$ at $37^{\circ} \mathrm{C}$ under agitation. Cells were gently pressed through a mesh, washed and re-suspended in 36\% Percoll $^{\mathbb{B}}$ in PBS (Sigma-Aldrich). The cell suspension was gently overlaid onto $70 \%$ Percoll $^{\mathbb{R}}$ and centrifuged for $30 \mathrm{~min}$ at $1350 \times \mathrm{g}$ at $4^{\circ} \mathrm{C}$. Lymphocytes were collected from the interface. The percentage of specific cytolysis was calculated as follows: $100-[(\%$ peptide pulsed cells in vaccinated mice/\% unpulsed cells in vaccinated mice)/ (\% peptide pulsed cells in control mice $/ \%$ unpulsed cells in control mice)] $\times 100$.

\section{Statistics}

For statistical analyses, groups from similar experiments were pooled and analyzed for significant differences as indicated in the graph. The $P$-values for experiment composites are given in the figure legends. All the statistical analyses were performed using Prism software (GraphPad Software, Inc.).

\section{RESULTS}

\section{PCa Peptide Antigens are Efficiently Encapsulated and Released From PLGA MS}

Characterization of the PLGA MS containing the eight PCa antigens $\mathrm{PSA}_{154-163}, \mathrm{PSCA}_{14-22}, \mathrm{PAP}_{112-120}$, TRPM8 ${ }_{187-195}$, PSMA $_{27-35}$, Survivin ${ }_{96-104}, \mathrm{STEAP1}_{86-94}$, and STEAP1 $1_{262-270}$ revealed that all peptide antigens could be encapsulated into the PLGA MS (Fig. 1, black bars). In addition, all the peptides were released from the microspheres in PBS (Fig. 1, white bars). The time interval for the release in aqueous medium mimics the time span of 6 days between immunization and analysis used in our in vivo immunization protocol. Furthermore, no overt differences in encapsulation efficiency and release were observable between the eight different PCa peptide antigens. 


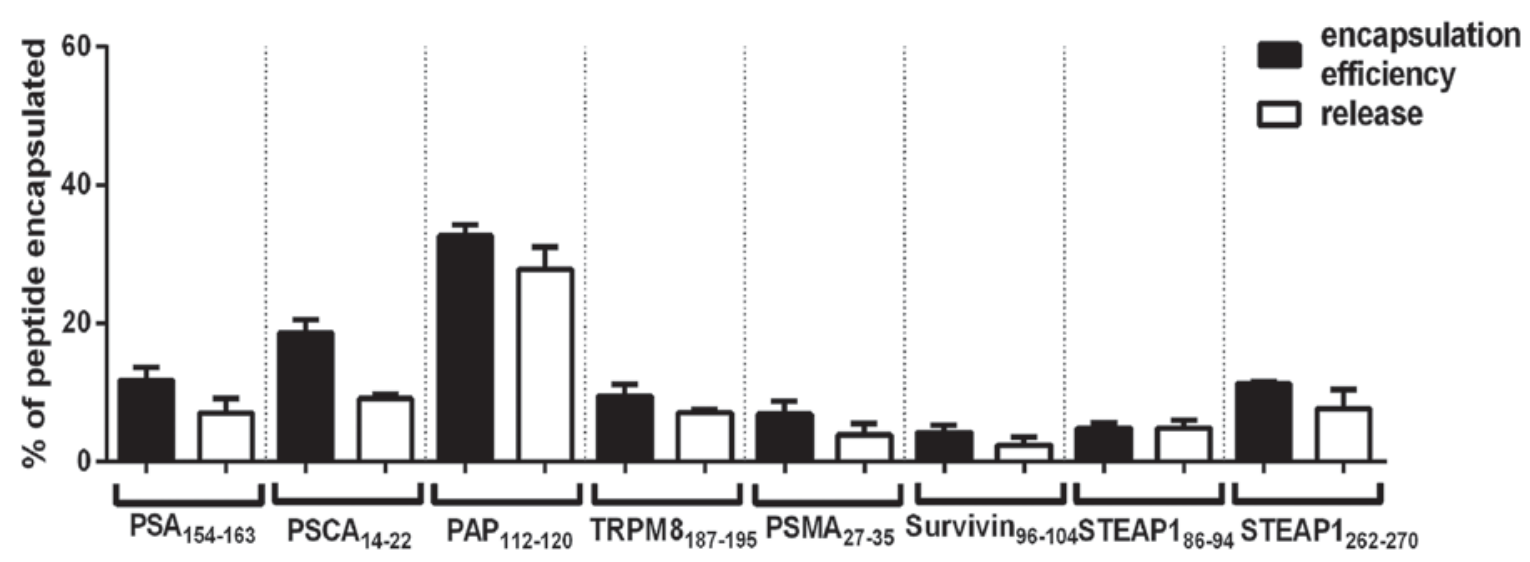

Fig. I. Characterization of PLGA encapsulated prostate carcinoma antigens by in vitro release. Encapsulation efficiency and release during 6 days in aqueous medium of peptide/CpG containing PLGA MS as determined by BCA assay. Assessed amounts of peptide were compared to theoretical maximal loading and given in percent encapsulation efficiency. The experiment has been repeated twice with similar outcome.

\section{PCa Peptide Antigens Bind and Stabilize HLA-A*020I}

One of the most important features of a peptide antigen is a strong binding and thus stabilization of MHC class I molecules. In silico analysis with the publically available epitope prediction programs SYFPEITHI (http://www.syfpeithi.de/) and BIMAS (http://www-bimas.cit.nih.gov/molbio/hla bind/) assigned excellent binding properties to all eight peptide antigens for HLA-A*0201. Stabilization of the HLA-A*0201 peptide complex on the cell surface was compared to the immunodominant, high affinity HLA-A*0201 ligand influenza virus matrix peptide $\mathrm{M}_{58-66}$. Like the $\mathrm{M} 1$ reference peptide, PSCA $_{14-22}$ and PSMA $_{27-35}$ stabilized HLA$\mathrm{A}^{*} 0201$ even at concentrations below $0.5 \mu \mathrm{M}$ (Fig. 2). All of the other antigens were also able to stabilize HLA-A*0201 already at low concentrations. PSA $_{154-163}$ and Survivin $96-104$ were the only epitopes that could not stabilize HLA-A*0201 as efficiently. In conclusion, all of the eight $\mathrm{PCa}$ peptide antigens can stabilize the HLA-A*0201 complex on the cell surface with low off rates.

\section{Superior Induction of a STEAP I $262-270-S p e c i f i c$ CTL Response by Immunization of HLA-A*020 I Transgenic Mice With PLGA MS as Compared to IFA}

Immunogenicity of the eight different PCa peptide antigens was assayed in vivo using AAD mice [33]. AAD mice express a transgene encoding an MHC class I fusion protein consisting of the peptide binding $\alpha 1$ and $\alpha 2$ domain of human HLA-A*0201 and the CD8 binding $\alpha 3$ domain of mouse $\mathrm{H}-2 \mathrm{D}^{\mathrm{d}}$. Corresponding amounts of PCa peptide as well as of the adjuvants $\mathrm{CpG-ODN}$ and polyI:C were either encapsulated into PLGA MS or emulsified in IFA. Vaccination with STEAP1 $262-270$, both in PLGA MS and IFA, induced peptide specific CTLs. A brief restimulation of these CTLs with STEAP1 $262-270$ peptide in vitro triggered a robust IFN- $\gamma$ response, which was significantly higher for the PLGA MS compared to IFA (Fig. 3A,B). Vaccination with only the adjuvants CpGODN and polyI:C encapsulated into PLGA MS served as negative control. Restimulation of the splenocytes from these control mice with STEAP1 ${ }_{262-270}$ peptide induced no IFN- $\gamma$ response. Surprisingly, vaccination with PSA ${ }_{154-163}$, PSCA $_{14-22}$, PAP $_{112-120}$, TRPM8 ${ }_{187-195}$, PSMA $_{27-35}$, Survivin $96-104$, and STEAP1 $1_{86-94}$ peptides co-encapsulated with CpG-ODN in PLGA MS and coadministered with polyI:C PLGA MS induced no peptide specific CTLs. This lack of a detectable CTL response was not only observed after PLGA MS-based vaccination but also when mice were vaccinated with the same peptides emulsified in IFA (Fig. 3A,B). The failure to elicit CTL responses for these seven PCa peptide antigens could, therefore, not be attributed to problems with PLGA MS specific encapsulation or release but most likely to marginal immunogenicity of these PCa peptide antigens in AAD mice.

\section{PLGA MS Induced CTLs Specifically Lyse Peptide-Loaded Target Cells In Vivo}

Next, the functionality of the generated STEAP $1_{262-270}$ specific CTLs in terms of their ability to lyse target cells in a peptide-specific manner was assayed. For vaccination with STEAP1 $1_{262-270} / \mathrm{CpG}$ MS and polyI:C MS the in vivo cytotoxicity assay showed robust responses. At day 6 after immunization STEAP1 $1_{262-270}$ pulsed target were specifically lysed both in spleen and liver whereas unpulsed 


\begin{tabular}{|l|l|r|r|}
\hline \multicolumn{1}{|c|}{ Peptide } & \multicolumn{1}{|c|}{ Sequence } & $\begin{array}{c}\text { Concentration to } \\
\text { stabilize MHC } \\
{[\mu \mathrm{M}]}\end{array}$ & Off-kinetics [h] \\
\hline FluM1 $_{58-66}$ & GILGFVFTL & $<0.5$ & $>>6$ \\
PSA $_{154-163}$ & VISNDVCAQV & 2 & 3 \\
PSCA $_{14-22}$ & ALQPGTALL & $<0.5$ & $>>6$ \\
PAP $_{112-120}$ & TLMSAMTNL & 1 & $>>6$ \\
TRPM8 $_{187-195}$ & GLMKYIGEV & 1 & $>>6$ \\
PSMA $_{27-35}$ & VLAGGFFLL & 1 & $>>6$ \\
Survivin $_{96-104}$ & LTLGEFLKL & 1 & 3 \\
STEAP $_{86-94}$ & FLYTLLREV & 1 & $>>6$ \\
STEAP $_{262-270}$ & LLLGTIHAL & $>>6$ \\
\hline
\end{tabular}

Fig. 2. HLA A*020I binding characteristics of the PCa peptide epitopes. For the stability assay, T2 cells were incubated at room temperature overnight with the indicated peptides over a range of peptide concentrations from 0.5 to $10 \mu \mathrm{M}$ in the presence of I $\mu \mathrm{g} / \mathrm{ml}$ $\beta_{2}$ microglobulin. The concentrations of the respective peptides needed to stabilize HLA $A^{*} 020 \mathrm{I}$ on the cell surface are provided. For the off kinetics, T2 cells were incubated overnight in the presence of $10 \mu \mathrm{M}$ peptide, followed by an incubation at $37^{\circ} \mathrm{C}$ in the presence of $50 \mu \mathrm{g} / \mathrm{ml}$ cycloheximide. Loss of HLA A*020I molecules from the cell surface (off kinetics) was monitored by flow cytometry after I, 2, 3, 4 , and $6 \mathrm{hr}$, respectively, as compared to cells incubated without peptide. The experiments have been performed twice with similar outcome.

control cells were not affected in the same mice (Fig. 4). In control mice immunized with CpG MS and polyI:C MS neither the peptide pulsed nor the unpulsed cells were lysed. In conclusion, CTLs induced by vaccination with PLGA MS containing STEAP1 $1_{262-270}$ were not only able to elicit an IFN- $\gamma$ response upon restimulation (Fig. 3) but also killed the target cells in a peptide-specific manner (Fig. 4). In contrast, CTLs of mice that were immunized with TRPM8 ${ }_{187-195} / \mathrm{CpG}$ MS and polyI:C MS did not lyse TRPM8 ${ }_{187-195}$ pulsed target cells, which is consistent with the finding that specific CTL responses could not be elicited after PLGA MS or IFA based vaccination (Fig. 3).

\section{PLGA MS Induced CTLs Recognize Human HLA- A*020 I/STEAP I 262-270 Complexes}

The first signal for the activation of primed $\mathrm{T}$ cells is provided through the T-cell receptor which interacts with peptide/MHC complexes on the surface of antigen presenting cells. Therefore, CTLs induced by vaccination with PLGA MS, including STEAP1 $1_{262-270}$ should recognize and respond to human APCs presenting STEAP1 $1_{262-270}$ peptide on HLA-A*0201. Indeed, splenocytes of vaccinated mice did not only respond upon peptide restimulation but also recognized and responded to peptide pulsed human prostate cancer cell lines LNCaP, PC3, and DU154 transfected with AAD and human HLA-A*0201 positive T2 cells (Fig. 5). Peptide specificity was analyzed by comparison to stimulation with unpulsed cells, which resulted in a significantly lower IFN- $\gamma$ release. The same result was observable for CTL stimulation with human monocyte-derived dendritic cells (MoDCs) raised from HLA-A*0201 positive donors after uptake of $\mathrm{STEAP}_{262-270} / \mathrm{CpG}$ MS leading to maturation of the MoDCs and to HLA-A*0201mediated peptide presentation on the cell surface. Stimulation with mature MoDCs after CpG MS uptake induced significantly less IFN- $\gamma$ producing CTLs. These data show that STEAP1 $262-270$ specific CTLs raised in HLA-A ${ }^{*} 0201 / H-2 D^{d}$ chimera expressing $\mathrm{AAD}$ mice recognize this peptide also on human HLA-A ${ }^{*} 0201$ and that human MoDC can be readily charged with the STEAP1 $1_{262-270}$ peptide by PLGA MS.

\section{DISCUSSION}

T-cell based immunotherapy of cancer is a promising non-invasive option for treatment of minimal residual disease, prevention of metastatic spread, and delay of recurrence without compromising quality of life. One of the major obstacles is the identification of possible antigenic peptide epitopes that are capable of initiating effective anti-tumor T-cell responses. 

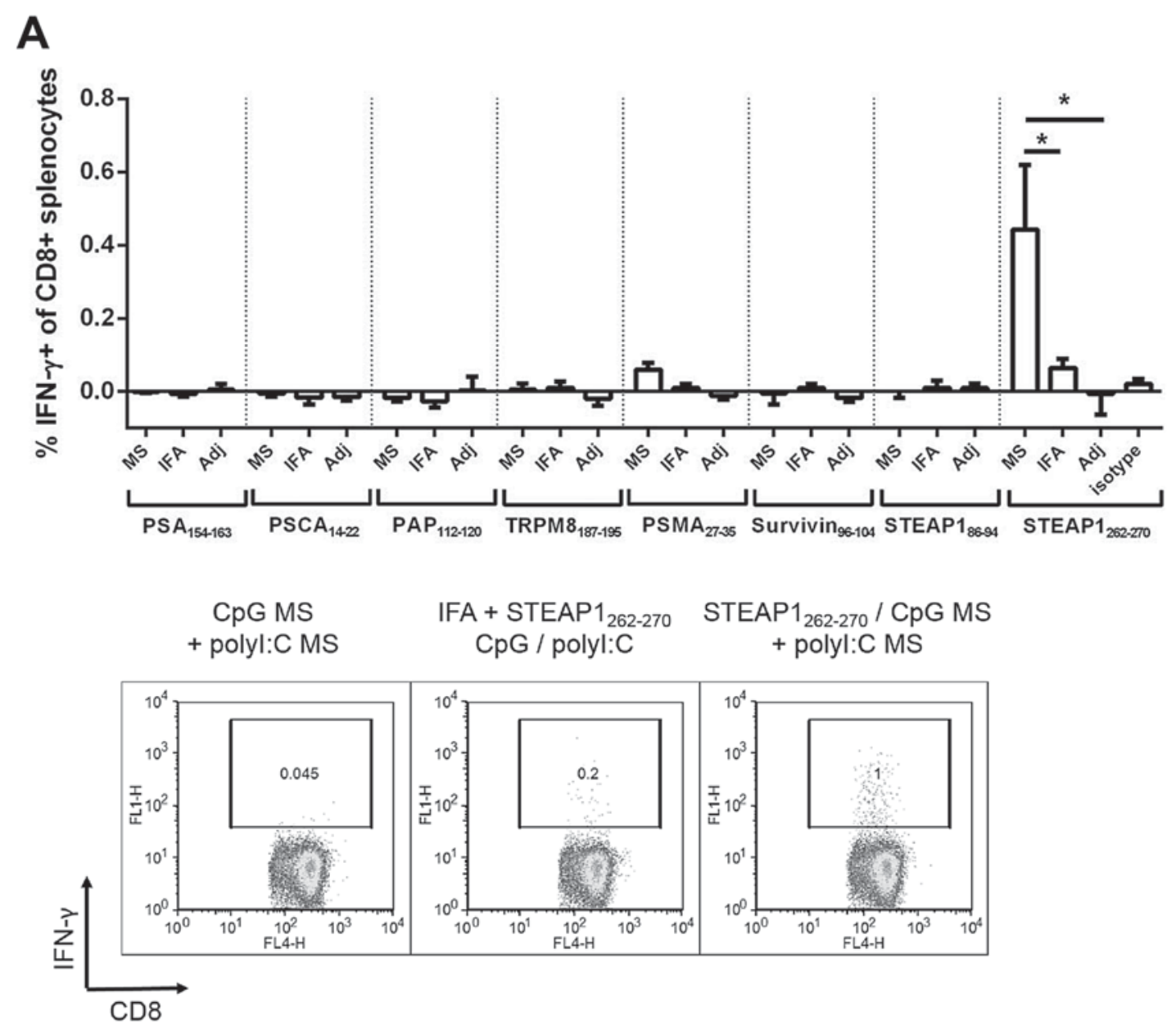

B

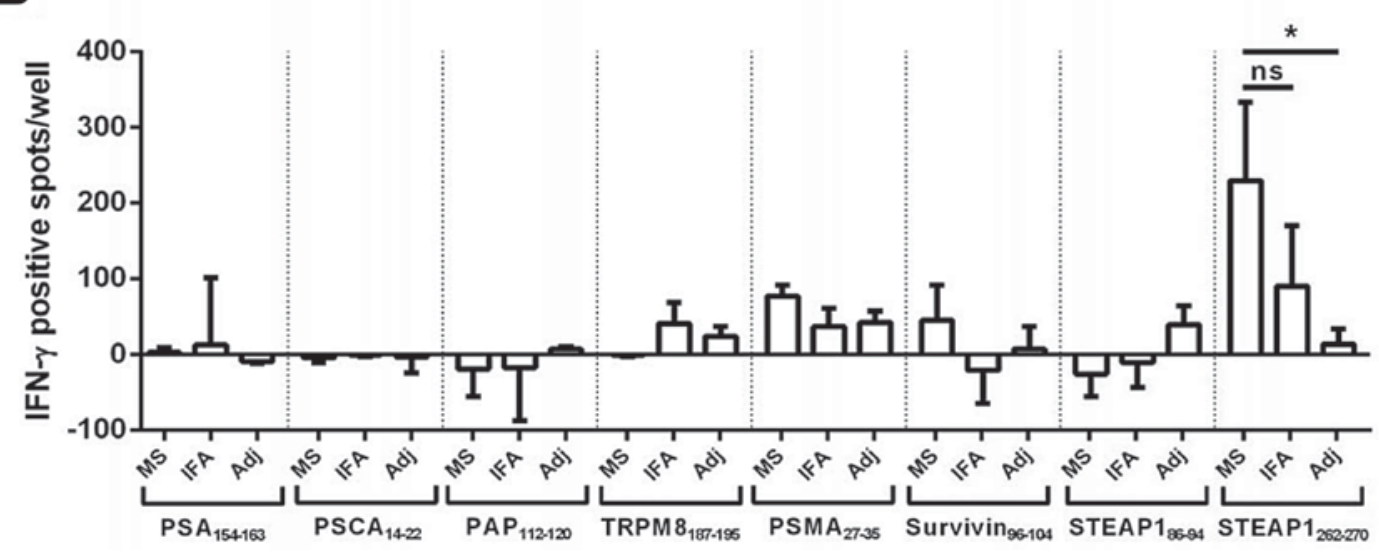

Fig. 3. Comparison of the CTL response after immunization with PLGA MS or IFA. Male HLA A*020I transgenic AAD mice $(n=3)$ were immunized with $5 \mathrm{mg}$ peptide/CpG MS and $5 \mathrm{mg}$ polyl:C MS per mouse (containing $50 \mu \mathrm{g}$ peptide, $25 \mu \mathrm{g}$ CpG, $2.5 \mu \mathrm{g}$ polyl:C). Alternatively, equivalent amounts of peptide, $\mathrm{CPG}$, and polyl:C were emulsified in IFA and used for vaccination. As control, adjuvants containing MS (Adj) incorporating only CPG and polyl:C were used. On day 6 after immunization splenocytes were isolated and analyzed for peptide specific CD8 ${ }^{+} \mathrm{T}$ cell responses by intracellular cytokine staining (ICS) for IFN $\gamma$ and flow cytometry (A) as well as ELISPOT assay (B). Representative examples of dot plots of the indicated ICS experiments are shown in (A) below the graph. Background levels (no peptide) were subtracted. Values (mean \pm SEM) in $(\mathbf{A})$ are given in percent IFN $\gamma^{+}$of $\mathrm{CD}^{+}$lymphocytes. The $P$ values of $(\mathbf{A})$ were calculated by an unpaired $t$ test with Welsch's correction $\left({ }^{*} P=0.0218 ;{ }^{*} P=0.0108\right)$. Values (mean $\left.\pm \mathrm{SEM}\right)$ in $(\mathbf{B})$ are given as IFN $\gamma$ specific spots/well. The $P$ value was calculated by an unpaired $t$ test with Welsch's correction $\left({ }^{*} P=0.0233\right)$. The experiments have been performed three times with similar outcome. 

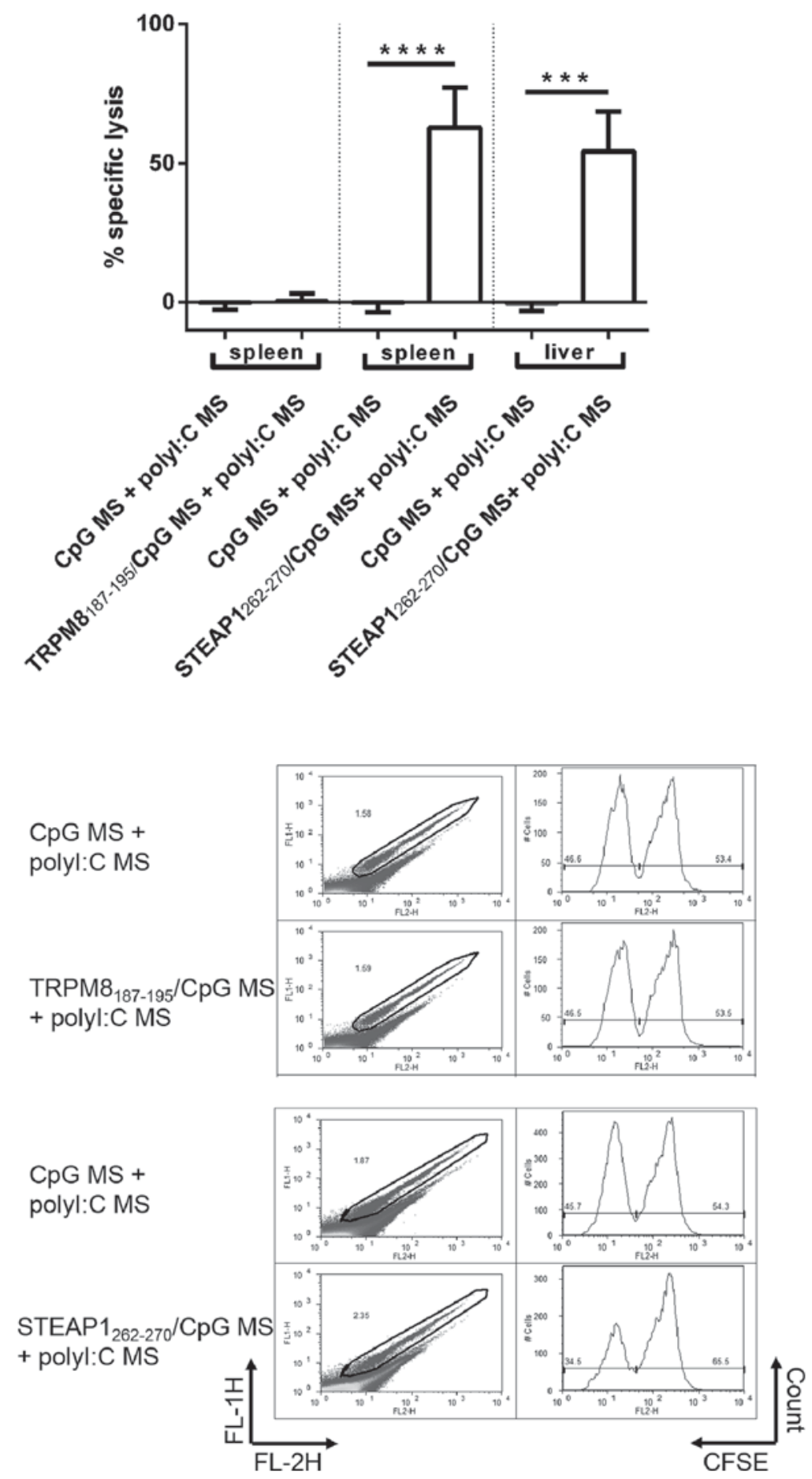

Fig. 4. CTL mediated in vivo cytotoxicity elicited by vaccination with PLGA MS. Male HLA $A^{*} 020$ I transgenic $A A D$ mice $(n=6)$ were

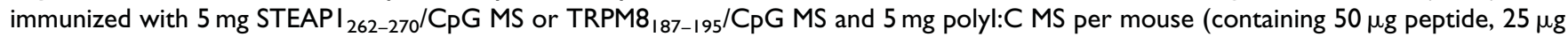
$\mathrm{CPG}_{\mathrm{P}} 2.5 \mu \mathrm{g}$ polyl:C). As controls adjuvants microspheres bearing respective amounts of CPG and polyl:C were used. On day 6 after immunization splenocytes from naive mice were depleted from erythrocytes. Half of the cells was left untreated, the other half was pulsed with $10^{-6} \mathrm{M}$ of the respective peptide for $1 \mathrm{hr}$ at $37^{\circ} \mathrm{C}$. Afterwards, untreated and peptide pulsed cells were stained with I $\mu \mathrm{M} / 10 \mu \mathrm{M}$ CFSE, respectively. A mixture of $\mathrm{I} \times 10^{7}$ pulsed and unpulsed cells was injected i.v. in the tail vein of the immunized mice. After $24 \mathrm{hr}$ splenocytes and liver lymphocytes of the immunized mice were analyzed for CFSE labeled cells by flow cytometry. Representative examples of flow cytometry histograms of CFSE labeled target cells from the mice immunized as indicated are shown below the graph. Values (mean \pm SEM) are given in percent specific lysis. The $P$ value was calculated by an unpaired $t$ test with Welsch's correction $\left({ }^{* * *} P=0.0008 ;{ }^{* * *} P=<0.000 \mathrm{I}\right)$. The experiments have been performed three time with similar results. 
A

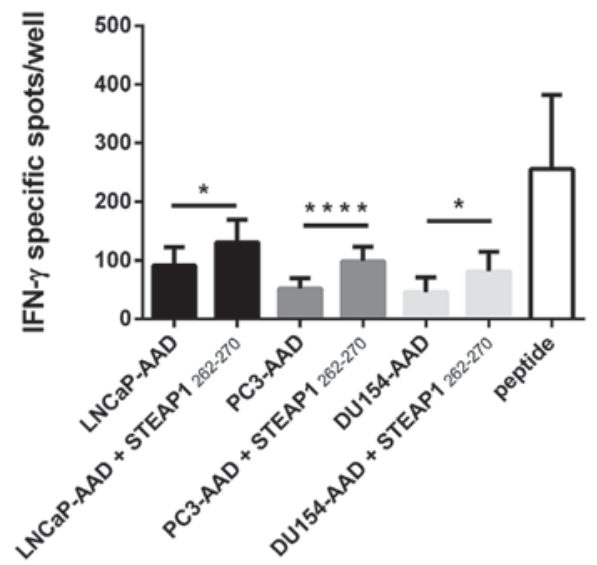

C

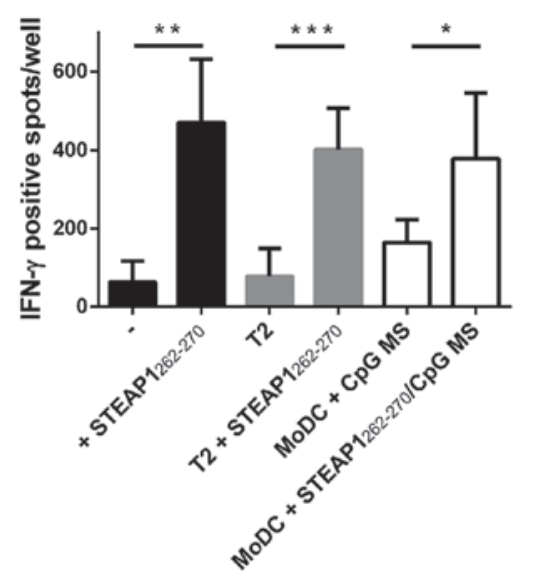

B

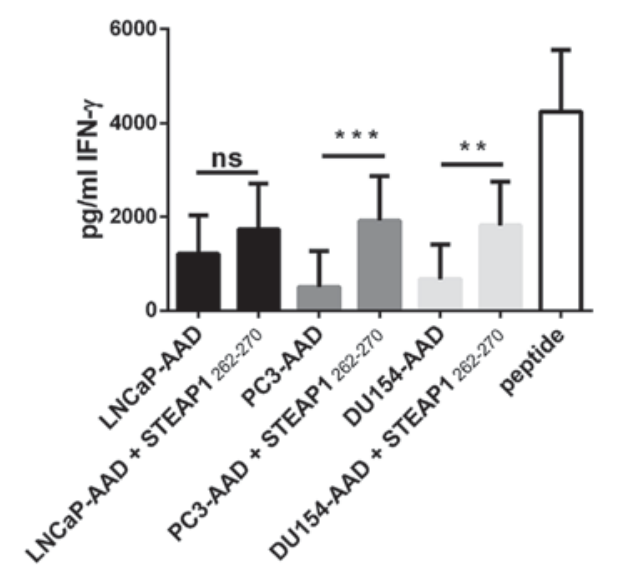

Fig. 5. STEAPI $262-270 / \mathrm{HLA} \mathrm{A}^{*} 020 \mathrm{I}$ recognition on PLGA MS pulsed human dendritic and prostate carcinoma cells by peptide specific CTLs. Male HLA A*020I transgenic AAD mice $(n=6)$ were immunized with $5 \mathrm{mg} \mathrm{STEAPI}{ }_{262-270} / \mathrm{CpG} M S$ and $5 \mathrm{mg}$ polyl:C MS per mouse. On day 6 after immunization splenocytes were isolated and stimulated by addition of either $+l$ STEAPI $262-270$ peptide alone (peptide), by (A,B) LNCaP AAD, PC3 AAD, DUI54 AAD cells externally pulsed or not with STEAPI 262-270 peptide or (C) T2 cells externally pulsed or not with STEAPI $262-270$ peptide, or by human $\mathrm{HLA} \mathrm{A}^{*} 020 \mathrm{I}^{+} \mathrm{MoDC}$ charged with $\mathrm{CPG} \mathrm{MS}$ alone or with STEAPI $262-270 / \mathrm{CPG}_{\mathrm{PS}}$. Peptide specific CD8 ${ }^{+} \mathrm{T}$ cell responses were detected in (B) by ELISA for IFN $\gamma$ in the supernatant; values (mean $\pm \mathrm{SEM}$ ) are given as $\mathrm{Pg} / \mathrm{ml}$ IFN $\gamma$. The $P$ values were calculated by an unpaired $t$ test $\left({ }^{* *} P=0.0010 ;{ }^{* *} P=0.0046\right)$. In $A$ and $C$, IFN $\gamma$ secretion of the $C T L s$ was detected by ELISPOT assays. Values (mean \pm SEM) are given as IFN $\gamma$ specific spots/well. The $P$ values were calculated by an unpaired $t$ test with Welsch's correction B: $\left({ }^{*} P=0.0155 ;{ }^{* * * *} P=<0.0001 ;{ }^{*} P=0.0104\right) / C:\left({ }^{* *} P=0.0010 ;{ }^{* * *} P=0.0002 ;{ }^{*} P=0.024 I\right)$. The experiments have been performed two times with similar outcome.

Ideal target epitopes are exclusively expressed in nonvital tissues, highly expressed in metastatic disease and accessible to therapeutic modalities [35]. All eight PCa epitopes used in this study scored very well for in silico predictions of HLA-A*0201 binding. Positive prognosis for their potential as antigenic epitopes by "reverse immunology" approaches was confirmed by the characterization of the HLA-A*0201 binding properties using the HLA-A*0201 positive human T2 cell line (Fig. 2). The efficacy of tumor immunotherapy is highly dependent on breaking the tolerance of the specific $\mathrm{CD} 8^{+} \mathrm{T}$ cell repertoire against the non-mutated self-tumor antigens [36]. Furthermore, cancer often coincidences with an immunosuppressive microenvironment within and around the tumor, characterized by the prevalence of immunosuppressive cytokines and high infiltration of regulatory $\mathrm{T}$ cells $[37,38]$. TLR agonists are being widely used to break immunological tolerance towards autologous TAAs and activate anti-cancer immune responses [39,40]. The utilization of CpG-ODN and polyI:C in our immunizations generates a strong Th1 


\begin{tabular}{|l|c|c|c|}
\hline & murine epitope & human epitope & $\begin{array}{c}\text { Grand average of } \\
\text { hydropathicity }\end{array}$ \\
\hline PSA $_{154-163}$ & lisndvcNqv * & visndvcaqv & 1.010 \\
PSCA $_{14-22}$ & alHpgAalQ & alqpgtall & 0.978 \\
PAP $_{12-120}$ & tlmsamtnl & tlmsamtnl & 0.833 \\
TRPM8 $_{187-195}$ & glmkyigev & glmkyigev & 0.544 \\
PSMA $_{27-35}$ & vlaLTGTFI & vlaggffll & 2.467 \\
Survivin $_{96-104}$ & ItVSeflkl & It|geflkl & 1.056 \\
STEAP1 $_{86-94}$ & flytllrel & flytllrev & 0.933 \\
STEAP1 $_{262-270}$ & IllgtVhal & Illgtihal & 1.911 \\
\hline \multicolumn{4}{|c|}{ "transmembrane protease serine 11G }
\end{tabular}

Fig. 6. Properties of the PCa epitopes. Comparison of the human PCa epitopes with their murine homologues. Non identical amino acids are marked with capital letters. The grand average hydropathicity was calculated as sum of the hydropathy values of all amino acids based on the Kyte Doolittle scale.

polarizing condition, which in combination with the usage of a peptide exclusively presented on HLA$\mathrm{A}^{*} 0201$ to $\mathrm{CD}^{+}$cytotoxic $\mathrm{T}$ cells, counteracts an unwanted Treg induction.

In the last decade, much work has been devoted to the investigation of DC-based immunotherapies. However, cultivation and antigen pulse of human DCs in vitro and injection of these cells into patients is a very labor and cost intensive approach which in addition yielded largely disappoint results [41-44]. The ideal tool for the improvement of DC-based immunotherapies is the usage of PLGA MS as antigen delivery system. PLGA MS are rapidly and efficiently taken up by immature dendritic cells in vitro and in vivo and release the encapsulated contents intracellularly in a sustained manner for processing and presentation on MHC class I and II molecules $[28,30,45]$. All PCa tumor antigens used in this study could be efficiently encapsulated into PLGA MS and were released during incubation in an aqueous environment (Fig. 1). Another antigen delivery system that has been used in numerous studies is incomplete Freund's adjuvant (IFA), a water-in-oil emulsion that can be mixed with antigens and pattern molecules. However, IFA has-in contrast to PLGA MS-some severe side effects like local skin irritations, inflammations, sterile abscesses, and cysts as well as persistent painful granulomas at the site of injection [46].

In our study, we showed that PLGA MS were even superior to IFA-based vaccination with STEAP1 $1_{262-270}$ peptide antigen and the TLR ligands CPG ODN and polyI:C in HLA-A*0201 transgenic AAD mice (Fig. 3). Unexpectedly, for all the other PCa antigen epitopes tested in this study neither PLGA MS nor IFA were able to induce peptide-specific CTLs. This result cannot be attributed to differences in the quality or purity of the used peptides as their identity was confirmed by mass spectrometry and their purity by HPLC analysis (data not shown). Moreover, only the PSA $_{154-163}$ peptide contains a cysteine which can be oxidized over time and hence become less immunogenic (Fig. 6). The immunogenic STEAP1 $1_{262-270}$ peptide has a high hydropathicity score (listed in Fig. 6) but so does PSMA $27-35$ which did not yield a CTL response in AAD mice. Yu et al. suggested that poor immunogenicity of self/tumor antigens derives from peptide/MHC-I instability rather than from tolerance [47], which we consider unlikely for these antigens as they all provide good HLA-A*0201 binding and stabilization characteristics (Fig. 2). As some of the antigens like $\mathrm{PAP}_{112-120}$ display complete and others like $\mathrm{PSMA}_{27-35}$ only minor conservation between human and mouse sequences neither the induction of xeno-CTLs nor self-tolerance seems to play a crucial role for the immunogenicity of the peptides (Fig. 6). The sole immunogenic epitope STEAP $1_{262-270}$ differs only in one conserved amino acid between the murine epitope (LLLGTVHAL) and its human homologue (LLLGTIHAL) used in this study. CTLs raised against human STEAP1 $1_{262-270}$ have even been shown to cross-react with mouse STEAP1 $1_{262-270}$ [48]. This suggests that a reduced tolerance induction against the human STEAP1 $1_{262-270}$ epitope in AAD mice cannot explain the superior CTL response to this peptide (Fig. 3). One could argue that the exclusive response to STEAP1 $1_{262-270}$ in AAD mice is due to a much higher CTL precursor frequency in the $\mathrm{T}$ cell repertoire of these mice. While a bias in the $\mathrm{T}$ cell repertoire can certainly contribute to this 
phenomenon, it seems unlikely that CTL precursors specific for seven other PCa epitopes are lacking in AAD mice given that they react to numerous other HLA-A*0201 epitopes [33]. Since the T cell repertoire in humans likely varies among individuals this parameter cannot easily be taken into consideration. Of note, the CTL response to the STEAP1 $1_{262-270}$ epitope was HLA-A*0201 specific as no immune response was detectable after immunization of C57BL/6 mice (data not shown). Vaccination with peptide epitopes obviously excludes the possibility of differences in antigen processing efficiencies, too.

Machlenkin et al. previously reported on the CTL inducing capability of a cell-based prime-boost vaccination with STEAP1 $1_{262-270}$ peptide-pulsed $\mathrm{DCs}$ in HLA-A2.1/H-2 $D^{\mathrm{b}}-\beta_{2}$ microglobulin monochain transgenic HHD mice in vivo and peptide induced CTL activity in vitro [48]. In agreement with these results, we were able to monitor in vivo cytolytic activity of the peptide specific CTLs, but already after a single vaccination with peptide-loaded PLGA MS (Fig. 4). The STEAP $1_{262-270}$ response elicited by MS was so strong, that its detection by IFN- $\gamma$ ICS or ELISPOT did not require CTL expansion by in vitro restimulation. Previously, it was shown that a CTL line specific for a modified version of another epitope of STEAP1 $\left(\mathrm{STEAP1} 1_{292-300}\right)$ could recognize HLA-A ${ }^{*} 0201^{+}$and $\mathrm{STEAP}^{+}$prostate cancer and other cell lines after in vitro restimulation [35]. We could show that STEAP $1_{262-270}$ specific CTLs, after a single immunization with PLGA MS containing the epitope, were not only able to recognize the epitope presented on HLA$\mathrm{A}^{*} 0201$ by T2 Lymphoblastoid cells and by three different human cancer cell lines on AAD but also on human MoDCs that present the epitope after PLGA MS uptake. STEAP1 is an ideal target for cancer immunotherapy as it is strongly expressed in multiple tumor types like prostate cancer, melanoma, colon cancer and Ewing's sarcoma, it has a restricted expression in normal tissues and cell surface localization [35]. Its localization at the cell-cell junctions of the secretory epithelium taken together with the six-transmembrane topology, suggests a function of STEAP1 as channel/ transporter protein in cell-cell junctions and an involvement in tumor growth [21] which may render an elimination of STEAP1 from PCa cells less likely.

\section{CONCLUSIONS}

We have shown that $\mathrm{STEAP} 1_{262-270}$ is the only out of eight possible antigenic peptide epitopes that was immunogenic enough to induce antigen specific CTLs after a single immunization with PLGA MS incorporating the peptide and the TLR ligand CpG ODN and polyI:C MS. It will now be attractive to test the PLGA
MS-based immunization against $\mathrm{STEAP}_{262-270}$ in pre-clinical models of PCa. As STEAP1 peptide can be produced in large scale and PLGA is a material approved for clinical application, immunotherapy of PCa with STEAP1 $1_{262-270}$ encapsulated into PLGA MS is a feasible, reproducible, and cost-effective approach which deserves to be developed for clinical testing in humans.

\section{ACKNOWLEDGMENTS}

Ilona Kindinger is acknowledged for experimental advice for MoDC preparation. We thank the personnel of the animal research facility of Konstanz University and Stefanie Buerger of the flow cytometry facility FlowKon. V.H. is a member of the DFG Research Training Group 1331 and D.E.W. is a member of the Konstanz Research School Chemical Biology. This project was funded by the German Cancer Aid and the Horizon 2020-NMP program of the European Commission, project Nr. 686089-2 (Precious).

\section{REFERENCES}

1. Siegel R, Ma J, Zou Z, Jemal A. Cancer statistics. CA Cancer J Clin 2014;64(1):9 29.

2. Coen JJ, Zietman AL, Thakral H, Shipley WU. Radical radiation for localized prostate cancer: Local persistence of disease results in a late wave of metastases. J Clin Oncol 2002;20(15):3199 3205.

3. Roehl KA, Han M, Ramos CG, Antenor JA, Catalona WJ. Cancer progression and survival rates following anatomical radical retropubic prostatectomy in 3,478 consecutive patients: long term results. J Urol 2004;172(3):910 914.

4. Risk M, Corman JM. The role of immunotherapy in prostate cancer: An overview of current approaches in development. Rev Urol 2009;11(1):16 27.

5. Tannock IF, de Wit R, Berry WR, Horti J, Pluzanska A, Chi KN, Oudard S, Theodore C, James ND, Turesson I, Rosenthal MA, Eisenberger MA. Docetaxel plus prednisone or mitoxantrone plus prednisone for advanced prostate cancer. N Engl J Med 2004;351(15):1502 1512.

6. de Bono JS, Oudard S, Ozguroglu M, Hansen S, Machiels JP, Kocak I, Gravis G, Bodrogi I, Mackenzie MJ, Shen L, Roessner M, Gupta S, Sartor AO. Prednisone plus cabazitaxel or mitoxantrone for metastatic castration resistant prostate cancer progressing after docetaxel treatment: A randomised open label trial. Lancet 2010;376(9747):1147 1154.

7. Ryan CJ, Smith MR, de Bono JS, Molina A, Logothetis CJ, de Souza P, Fizazi K, Mainwaring P, Piulats JM, Ng S, Carles J, Mulders PFA, Basch E, Small EJ, Saad F, Schrijvers D, Van Poppel H, Mukherjee SD, Suttmann H, Gerritsen WR, Flaig TW, George DJ, Yu EY, Efstathiou E, Pantuck A, Winquist E, Higano CS, Taplin M E, Park Y, Kheoh T, Griffin T, Scher HI, Rathkopf DE. Abiraterone in metastatic prostate cancer without previous chemotherapy. N Engl J Med 2013;368(2):138 148.

8. Scher HI, Fizazi K, Saad F, Taplin ME, Sternberg CN, Miller K, de Wit R, Mulders P, Chi KN, Shore ND, Armstrong AJ, Flaig TW, Flechon A, Mainwaring P, Fleming M, Hainsworth JD, Hirmand M, Selby B, Seely L, de Bono JS. Increased survival 
with enzalutamide in prostate cancer after chemotherapy. N Engl J Med 2012;367(13):1187 1197.

9. Parker C, Nilsson S, Heinrich D, Helle SI, O'Sullivan JM, Fossa SD, Chodacki A, Wiechno P, Logue J, Seke M, Widmark A, Johannessen DC, Hoskin P, Bottomley D, James ND, Solberg A, Syndikus I, Kliment J, Wedel S, Boehmer S, Dall'Oglio M, Franzen L, Coleman R, Vogelzang NJ, O'Bryan Tear CG, Staudacher K, Garcia Vargas J, Shan M, Bruland OS, Sartor O. Alpha emitter radium 223 and survival in metastatic prostate cancer. N Engl J Med 2013;369(3):213 223.

10. Small EJ, Schellhammer PF, Higano CS, Redfern $\mathrm{CH}$, Nemunaitis JJ, Valone FH, Verjee SS, Jones LA, Hershberg RM. Placebo controlled phase III trial of immunologic therapy with sipuleucel $\mathrm{T}$ (APC8015) in patients with metastatic, asymptomatic hormone refractory prostate cancer. J Clin Oncol 2006;24(19):3089 3094.

11. Robert C, Thomas L, Bondarenko I, O'Day S, Weber J, Garbe C, Lebbe C, Baurain JF, Testori A, Grob JJ, Davidson N, Richards J, Maio M, Hauschild A, Miller WH Jr., Gascon P, Lotem M, Harmankaya K, Ibrahim R, Francis S, Chen TT, Humphrey R, Hoos A, Wolchok JD. Ipilimumab plus dacarbazine for previ ously untreated metastatic melanoma. N Engl J Med 2011;364 (26):2517 2526.

12. Brahmer JR, Drake CG, Wollner I, Powderly JD, Picus J, Sharfman WH, Stankevich E, Pons A, Salay TM, McMiller TL, Gilson MM, Wang C, Selby M, Taube JM, Anders R, Chen L, Korman AJ, Pardoll DM, Lowy I, Topalian SL. Phase I study of single agent anti programmed death 1 (MDX 1106) in refractory solid tumors: Safety, clinical activity, pharmacodynamics, and immunologic correlates. J Clin Oncol 2010;28(19):3167 3175.

13. Rosenberg SA. Cancer vaccines based on the identification of genes encoding cancer regression antigens. Immunol Today 1997;18(4):175 182.

14. Oesterling JE. Prostate specific antigen: A critical assessment of the most useful tumor marker for adenocarcinoma of the prostate. J Urol 1991;145(5):907 923.

15. Murphy GP, Elgamal AA, Su SL, Bostwick DG, Holmes EH. Current evaluation of the tissue localization and diagnostic utility of prostate specific membrane antigen. Cancer 1998;83 (11):2259 2269 .

16. Solin T, Kontturi M, Pohlmann R, Vihko P. Gene expression and prostate specificity of human prostatic acid phosphatase (PAP): Evaluation by RNA blot analyses. Biochim Biophys Acta 1990;1048(1):72 77.

17. Reiter RE, Gu Z, Watabe T, Thomas G, Szigeti K, Davis E, Wahl M, Nisitani S, Yamashiro J, Le Beau MM, Loda M, Witte ON. Prostate stem cell antigen: A cell surface marker overex pressed in prostate cancer. Proc Natl Acad Sci USA 1998;95 (4):1735 1740

18. Dannull J, Diener PA, Prikler L, Furstenberger G, Cerny T, Schmid U, Ackermann DK, Groettrup M. Prostate stem cell antigen is a promising candidate for immunotherapy of advanced prostate cancer. Cancer Res 2000;60(19):5522 5528 .

19. Tsavaler L, Shapero MH, Morkowski S, Laus R. Trp p8, a novel prostate specific gene, is up regulated in prostate cancer and other malignancies and shares high homology with transient receptor potential calcium channel proteins. Cancer Res 2001;61(9):3760 3769 .

20. Hubert RS, Vivanco I, Chen E, Rastegar S, Leong K, Mitchell SC, Madraswala R, Zhou Y, Kuo J, Raitano AB, Jakobovits A, Saffran DC, Afar DE. STEAP: a prostate specific cell surface antigen highly expressed in human prostate tumors. Proc Natl Acad Sci USA 1999;96(25):14523 14528.
21. Challita Eid PM, Morrison K, Etessami S, An Z, Morrison KJ, Perez Villar JJ, Raitano AB, Jia XC, Gudas JM, Kanner SB, Jakobovits A. Monoclonal antibodies to six transmembrane epithelial antigen of the prostate 1 inhibit intercellular commu nication in vitro and growth of human tumor xenografts in vivo. Cancer Res 2007;67(12):5798 5805.

22. Koike H, Sekine Y, Kamiya M, Nakazato H, Suzuki K. Gene expression of survivin and its spliced isoforms associated with proliferation and aggressive phenotypes of prostate cancer. Urology 2008;72(6):1229 1233.

23. Escors D. Tumour immunogenicity, antigen presentation and immunological barriers in cancer immunotherapy. New J Sci 2014; doi: $10.1155 / 2014 / 734515$

24. Waeckerle Men Y, Groettrup M. PLGA microspheres for im proved antigen delivery to dendritic cells as cellular vaccines. Adv Drug Deliv Rev 2005;57(3):475 482.

25. Malyala P, O'Hagan DT, Singh M. Enhancing the therapeutic efficacy of $\mathrm{CPG}$ oligonucleotides using biodegradable micro particles. Adv Drug Deliv Rev 2009;61(3):218 225.

26. Akagi T, Wang X, Uto T, Baba M, Akashi M. Protein direct delivery to dendritic cells using nanoparticles based on amphi philic poly(amino acid) derivatives. Biomaterials 2007;28 (23):3427 3436

27. Mueller M, Schlosser E, Gander B, Groettrup M. Tumor eradication by immunotherapy with biodegradable PLGA microspheres an alternative to incomplete Freund's adjuvant. Int J Cancer 2011;129(2):407 416.

28. Waeckerle Men Y, Scandella E, Uetz Von Allmen E, Ludewig B, Gillessen S, Merkle HP, Gander B, Groettrup M. Phenotype and functional analysis of human monocyte derived dendritic cells loaded with biodegradable poly(lactide co glycolide) microspheres for immunotherapy. J Immunol Methods 2004;287(1 2):109 124.

29. Audran R, Peter K, Dannull J, Men Y, Scandella E, Groettrup M, Gander B, Corradin G. Encapsulation of peptides in biodegrad able microspheres prolongs their MHC class I presentation by dendritic cells and macrophages in vitro. Vaccine 2003;21(11 12):1250 1255.

30. Waeckerle Men Y, Allmen EU, Gander B, Scandella E, Schlosser E, Schmidtke G, Merkle HP, Groettrup M. Encapsulation of proteins and peptides into biodegradable poly(D,L lactide co glycolide) microspheres prolongs and enhances antigen presen tation by human dendritic cells. Vaccine 2006;24(11):1847 1857.

31. Schlosser E, Mueller M, Fischer S, Basta S, Busch DH, Gander B, Groettrup M. TLR ligands and antigen need to be coencapsu lated into the same biodegradable microsphere for the genera tion of potent cytotoxic $\mathrm{T}$ lymphocyte responses. Vaccine 2008;26(13):1626 1637.

32. Waeckerle Men Y, Gander B, Groettrup M. Delivery of tumor antigens to dendritic cells using biodegradable microspheres. Methods Mol Med 2005;109:35 46 .

33. Newberg MH, Smith DH, Haertel SB, Vining DR, Lacy E, Engelhard VH. Importance of MHC class 1 alpha2 and alpha3 domains in the recognition of self and non self MHC molecules. J Immunol 1996;156(7):2473 2480.

34. Waeckerle Men Y, Allmen EU v, von Moos R, Classon BJ, Scandella E, Schmid H P, Ludewig B, Groettrup M, Gillessen $\mathrm{S}$. Dendritic cells generated from patients with androgen independent prostate cancer are not impaired in migration and T cell stimulation. The Prostate 2005;64(4):323 331.

35. Rodeberg DA, Nuss RA, Elsawa SF, Celis E. Recognition of six transmembrane epithelial antigen of the prostate expressing 
tumor cells by peptide antigen induced cytotoxic $\mathrm{T}$ lympho cytes. Clin Cancer Res 2005;11(12):4545 4552.

36. Bai XF, Liu J, Li O, Zheng $\mathrm{P}$, Liu $\mathrm{Y}$. Antigenic drift as a mechanism for tumor evasion of destruction by cytolytic $\mathrm{T}$ lymphocytes. J Clin Invest 2003;111(10):1487 1496.

37. Tanchot C, Terme M, Pere H, Tran T, Benhamouda N, Strioga M, Banissi C, Galluzzi L, Kroemer G, Tartour E. Tumor infiltrating regulatory $\mathrm{T}$ cells: Phenotype, role, mechanism of expansion in situ and clinical significance. Cancer Microenviron 2013;6(2):147 157.

38. van der Burg SH, Melief CJ. Therapeutic vaccination against human papilloma virus induced malignancies. Curr Opin Immunol 2011;23(2):252 257.

39. Lim SN, Kuhn S, Hyde E, Ronchese F. Combined TLR stimula tion with Pam3Cys and Poly I: C enhances Flt3 ligand dendritic cell activation for tumor immunotherapy. J Immunother 2012;35(9):670 679.

40. Xiao H, Peng Y, Hong Y, Huang L, Guo ZS, Bartlett DL, Fu N, Munn DH, Mellor A, He Y. Local administration of TLR ligands rescues the function of tumor infiltrating CD8 $\mathrm{T}$ cells and enhances the antitumor effect of lentivector immunization. J Immunol 2013;190(11):5866 5873 .

41. Nestle FO, Alijagic S, Gilliet M, Sun Y, Grabbe S, Dummer R, Burg G, Schadendorf D. Vaccination of melanoma patients with peptide or tumor lysate pulsed dendritic cells. Nat Med 1998;4(3):328 332.

42. Schuler Thurner B, Schultz ES, Berger TG, Weinlich G, Ebner S, Woerl P, Bender A, Feuerstein B, Fritsch PO, Romani N, Schuler G. Rapid induction of tumor specific type $1 \mathrm{~T}$ helper cells in metastatic melanoma patients by vaccination with mature, cryopreserved, peptide loaded monocyte derived dendritic cells. J Exp Med 2002;195(10):1279 1288.
43. Schuler G, Schuler Thurner B, Steinman RM. The use of dendritic cells in cancer immunotherapy. Curr Opin Immunol 2003;15(2):138 147

44. Waeckerle Men $\mathrm{Y}$, Uetz von Allmen E, Fopp M, von Moos R, Bohme C, Schmid H P, Ackermann D, Cerny T, Ludewig B, Groettrup M, Gillessen S. Dendritic cell based multi epitope immunotherapy of hormone refractory prostate carcinoma. Cancer Immunol Immun 2006;55(12):1524 1533.

45. Schliehe C, Redaelli C, Engelhardt S, Fehlings M, Mueller M, van Rooijen N, Thiry M, Hildner K, Weller H, Groettrup M. CD8 dendritic cells and macrophages cross present poly(D,L lactate co glycolate) acid microsphere encapsulated antigen in vivo. J Immunol 2011;187(5):2112 2121.

46. Toledo H, Baly A, Castro O, Resik S, Laferte J, Rolo F, Navea L, Lobaina L, Cruz O, Miguez J, Serrano T, Sierra B, Perez L, Ricardo ME, Dubed M, Lubian AL, Blanco M, Millan JC, Ortega A, Iglesias E, Penton E, Martin Z, Perez J, Diaz M, Duarte CA. A phase I clinical trial of a multi epitope polypeptide TAB9 combined with Montanide ISA 720 adju vant in non HIV 1 infected human volunteers. Vaccine 2001;19(30):4328 4336.

47. Yu Z, Theoret MR, Touloukian CE, Surman DR, Garman SC, Feigenbaum L, Baxter TK, Baker BM, Restifo NP. Poor immuno genicity of a self/tumor antigen derives from peptide MHC I instability and is independent of tolerance. J Clin Invest 2004;114(4):551 559.

48. Machlenkin A, Paz A, Bar Haim E, Goldberger O, Finkel E, Tirosh B, Volovitz I, Vadai E, Lugassy G, Cytron S, Lemonnier F, Tzehoval E, Eisenbach L. Human CTL epitopes prostatic acid phosphatase 3 and six transmembrane epithelial antigen of prostate 3 as candidates for prostate cancer immunotherapy. Cancer Res 2005;65(14):6435 6442. 